\title{
Olfactory Bulb
}

National Cancer Institute

\section{Source}

National Cancer Institute. Olfactory Bulb. NCI Thesaurus. Code C28401.

Anatomical structure located in the vertebral forebrain that receives neural input regarding odors that have been detected by cells within the nasal cavity. The axons of olfactory receptor cells extend into the olfactory bulb. 